\title{
Russia as Civilization: Ideological Discourses in Politics, Media, and Academia
}

Kåre Johan Mjør \& Sanna Turoma (red.)

Abingdon: Routledge 2020

227 + xix sider. ISBN 9780367493851

Omtalt av Pål Kolstø [professor i Russland-studier, Institutt for litteratur, områdestudier og europeiske språk, Universitet i Oslo, pal.kolsto@ilos.uio.no]

I artikkelen «Russland - det nasjonale spørsmål» fra 2012 omtalte Vladimir Putin Russland som en "stat-sivilisasjon». Dermed ble sivilisasjonsretorikk en sentral del av Putin-regimets legitimeringsstrategi, i hvert fall for en stund. Russia as Civilization beskriver og analyserer hvordan sivilisasjonsbegrepet har vært brukt og misbrukt i russisk politisk og kulturell diskurs i de senere årene, med et lite tilbakeblikk også på sen-sovjetisk ideologiproduksjon.

Boken består av 10 kapitler skrevet av russiske og skandinaviske forfattere. De fleste av tekstene er lett tilgjengelige, men samtidig svært lærde og grundige, med lange litteraturlister - rekorden har Viktor Sjnirelman med en 10 siders bibliografi til en 17 siders artikkel. Boken er ikke lang - under 250 sider - men når man har lest ferdig, er man (i hvert fall denne anmelderen) overbevist om at man har lært det som er verdt å vite - og enda litt til - om Putin-tidens russiske sivilisasjonsdebatt.

Noen av forfatterne fokuserer ikke på sivilisasjonsbegrepet direkte, men diskuterer i stedet idékomplekser og kulturuttrykk som tangerer sivilisasjonsproblematikken. Dette gjelder for eksempel Maria Engströms interessante kunsthistoriske analyse av Kremls kulturpolitikk og Vesa Oittinens gjennomgang av sovjetmarxistenes bruk av Marx' teori om «sosioøkonomiske formasjoner» og hvordan dette nokså sterile begrepet på 1980-tallet måtte konkurrere med ansatser til en ny ideologisering rundt sivilisasjonsbegrepet.

Også Olga Malinova og Tatjana Rjabova har egentlig nokså lite å si om «Russia as civilization», men tar opp beslektede fenomener i russisk idéhistorie og propaganda. Malinova tar et bredt sveip over russisk identitetsdebatt og fokuserer på forholdet mellom begrepene «nasjon», «imperium» og «sivilisasjon», mens Rjabova gjennom et stort antall eksempler viser hvordan «folkelig geopolitikk» i Russland fremstiller dette landet som maskulint og USA som feminint. Som leser følte jeg vel 
egentlig at Rjabova hadde fått frem poenget nokså tidlig i artikkelen, og at mye av den videre dokumentasjonen var «overkill».

Noen av de mest lesverdige bidragene til boken står redaktørene selv for. Kåre Johan Mjør og Sanna Turoma diskuterer i sin innledning den nye russiske sivilisasjonsdebatten $i$ en videre europeisk og historisk kontekst og plasserer den i forhold til spenglerianisme, eurasianisme og Samuel Huntingtons "clash of civilizations». Selv om Huntingtons «teori» er populær i Russland, påpeker forfatterne at den russiske sivilisasjonsdebatten ikke står i gjeld til ham, men har eldre røtter. Putin selv har for øvrig ikke hentet begrepet fra Huntington, men sannsynligvis fra den konservative tenkeren Mikhail Remizov, som visstnok er den første som brukte den snurrige ordkombinasjonen «stat-sivilisasjon».

I et annet kapittel tar Mjør for seg én enkelt ideologiprodusent, Oleg Platonov, som i de fleste fremstillinger av russisk nasjonalisme og konservatisme går under radaren, men som viser seg å være en svært viktig premissleverandør. Platonov står bak opprettelsen av Institutt for russisk sivilisasjon, en institusjon som hovedsakelig beskjeftiger seg med å utgi eldre russiske idéhistoriske tekster. Slik gjør han tilgjengelig mange kjente - og noen mindre kjente - tenkere som ellers ikke er å få tak i, og ja, jeg har selv et titalls av bøker utgitt av Institutt for russisk sivilisasjon i bokhyllen. Før jeg leste Mjørs kapittel var jeg ikke klar over at Platonov er tilhenger av Ioann (Snytsjev), som var den russiske kirkes metropolitt i St. Petersburg på 1990-tallet og beryktet for sin antisemittisme og sine apokalyptiske endetidsprofetier. I omtalen av bøkene han gir ut, sniker Platonov inn så mye han kan av sin læremesters tankegods på kolofonsiden. Men hvor mange leser egentlig kolofonside-tekster?

Et annet kapittel som er verd å trekke frem, er Sjnirelmans «Russia between a civilization and a civic nation: secular and religious uses of civilizational discourse during Putin's third term». Sjnirelman tar for seg sivilisasjonsdebatten i den politiske eliten og i den russisk-ortodokse kirken og diskuterer forholdet mellom disse. Han påpeker at Putin etter 2012-artikkelen så å si ikke har brukt sivilisasjonsbegrepet, og når Sjnirelman skriver dette, kan vi stole på at det er riktig, han gjør alltid grundig research. Av dette trekker han den konklusjon at «Putin and his assistants use the term 'civilization' instrumentally rather than conceptually. They use it when social consolidation is at stake and when there is a need to set Russia against the West» (s. 67). Det er derfor feil å snakke om noen "long-term civilizational turn» i russisk politikk og ideologi, slik enkelte forskere gjør, mener Sjnirelman.

Derimot finner han en langt mer utbredt bruk av sivilisasjonsbegrepet blant kirkens menn, særlig når de henvender seg til et bredere publikum utenfor kretsen av troende. Kirken har tatt initiativet til en World Russian People's Assembly der «russisk sivilisasjon» inngår som en helt sentral del av det retoriske repertoaret. Likevel, bemerker Sjnirelman, «recently 'Russian civilization' has evidently become a less important concept for both the Russian authorities and the Church» (s. 75). Hvis dette er riktig, kan det være at hele ideen om Russland som en egen "(stats)sivilisasjon» er et blaff mer enn en ny trend, og at Mjør og Turomas bok dokumenterer et ideologisk og retorisk fenomen som allerede er et lukket historisk kapittel. 